\title{
Review
}

\section{Carcinogenesis, cancer therapy and chemoprevention}

\author{
MV Blagosklonny ${ }^{\star, 1}$ \\ 1 Brander Cancer Research Institute, New York Medical College, 19 Bradhurst \\ Ave., Hawthorne, NY 10532, USA \\ * Corresponding author: Cancer Center, Ordway Research Institute, 150 New \\ Scotland Avenue, Albany, NY 12208, USA. Tel: 914347 2801; \\ Fax: 518641 6305; E-mail: blagosklonny@ hotmail.com
}

Received 03.12.04; revised 10.1.05; accepted 17.1.05; published online 08.4.05 Edited by G Melino

\begin{abstract}
Carcinogenesis and cancer therapy are two sides of the same coin, such that the same cytotoxic agent can cause cancer and be used to treat cancer. This review links carcinogenesis, chemoprevention and cancer therapy in one process driven by cytotoxic agents (carcinoagents) that select either for or against cells with oncogenic alterations. By unifying therapy and cancer promotion and by distinguishing nononcogenic and oncogenic mechanisms of resistance, I discuss anticancer- and chemopreventive agent-induced carcinogenesis and tumor progression and, vice versa, carcinogens as anticancer drugs, anticancer drugs as chemopreventive agents and exploiting oncogene-addiction and drug resistance for chemoprevention and cancer therapy.

Cell Death and Differentiation (2005) 12, 592-602.

doi:10.1038/sj.cdd. 4401610

Published online 8 April 2005
\end{abstract}

Keywords: carcinogenesis; cancer therapy; chemoprevention

Abbreviations: MGMT, O6-methylguanine-DNA methyltransferase

\section{Introduction}

Some notions in cancer biology and oncology may seem conflicting. For example, avoidance of apoptosis is a hallmark of cancer. ${ }^{1-6}$ On the other hand, it is often presumed that anticancer drugs should induce apoptosis preferentially in cancer cells. Even inhibitors of universally vital targets such as of histone deacetylases and the proteasome are asserted to be selectively toxic to cancer cells. On the one hand, it is well recognized that genetic instability (e.g., through defects in DNA repair) predisposes to cancer and accelerates tumor progression. ${ }^{7,8}$ On the other hand, inhibition of DNA repair assists in treating cancer. ${ }^{9,10}$

Although carcinogens and anticancer drugs are viewed as opposites, the two groups of agents highly overlap (Figure 1):

a. Alkylating agents are classic carcinogens (methylnitrosourea, 7,12-dimethylbenzanthracene, diethylnitrosoamine) and also they are classic anticancer drugs (melphalan, chlorambucil, busulfan, cyclophosphamide, the nitrosoureas, cisplatinum and carboplatin). ${ }^{11-14}$

b. Radiation is both a carcinogenic agent and an effective anticancer therapy. As a striking example, radioactive iodine causes thyroid cancer ${ }^{15}$ and is the most effective therapy for thyroid cancers that retain the ability to accumulate iodine. ${ }^{16}$

c. Arsenic, a classic cytotoxic agent and carcinogen, recently was re-discovered as one of the most promising antileukemia and anticancer drugs. ${ }^{17,18}$

d. Tamoxifen, an antiestrogen, which is effective in therapy of breast cancer, can cause endometrial cancer ${ }^{19,20}$ and malignant mixed mullerian tumors. ${ }^{21}$

e. For 25 years, it was well known that phorbol ester (PMA) TPA) inhibits proliferation of leukemia cells. Yet, for many years, TPA was not considered for clinical use, because TPA is carcinogenic. In pioneering clinical trials (initiated by Allan Conney), TPA caused clinical remissions in patients who were refractory to chemotherapy. ${ }^{22-24}$ Combinations of TPA with other experimental therapeutics are under preclinical investigations. $^{25}$ Similarly, anticancer drugs, especially topoisomerase inhibitors, cause secondary cancers. ${ }^{26-29}$ To complicate matters further, chemopreventive agents may promote cancer in some conditions. ${ }^{30}$ In certain mice, sulindac, a nonsteroidal anti-inflammatory drug, prevents tumors in the small intestine but increases the incidence of tumors in the large intestine. ${ }^{31}$ Retinoic acid prevents papillomas but accelerates progression from papillomas to carcinomas. ${ }^{32}$ Tamoxifen can prevent breast cancer, ${ }^{33}$ while increasing the risk of endometrial cancer. ${ }^{34}$ In a chemoprevention trial, beta-carotene was unexpectedly found to increase both the risk of lung cancer among high-risk groups ${ }^{35}$ and colorectal adenomas. ${ }^{36}$ Genistein, a chemopreventive agent, ${ }^{37}$ increases carcinogen-induced mammary tumorigenesis in female rat offspring. ${ }^{38}$ In women, even such chemopreventive agents as aspirin can increase the risk of pancreatic cancer. ${ }^{39}$ Selenium, a chemopreventive agent, can increase squamous cell carcinomas. ${ }^{40}$

To reconcile these seemingly conflicting data, this review links tumor progression to cancer therapy to chemoprevention. Since each field is enormously complex by itself, this review cannot discuss them in detail. Instead, it is focused on common underlying principles such as selection for resistance to cytotoxic agents. The notion that carcinogenesis is associated with acquiring resistance to cytotoxic carcinogens is not particularly novel. ${ }^{41}$ Yet, these ideas were viewed as an alternative to the somatic mutation theory. They were not integrated in the concept that cancer results from accumulation of genetic and epigenetic alterations in oncogenes and tumor suppressors. $^{42}$ This article combines both concepts. We distinguish oncogenic resistance (due to oncogenic mutations that alter cell cycle and apoptotic pathways) and nononcogenic 


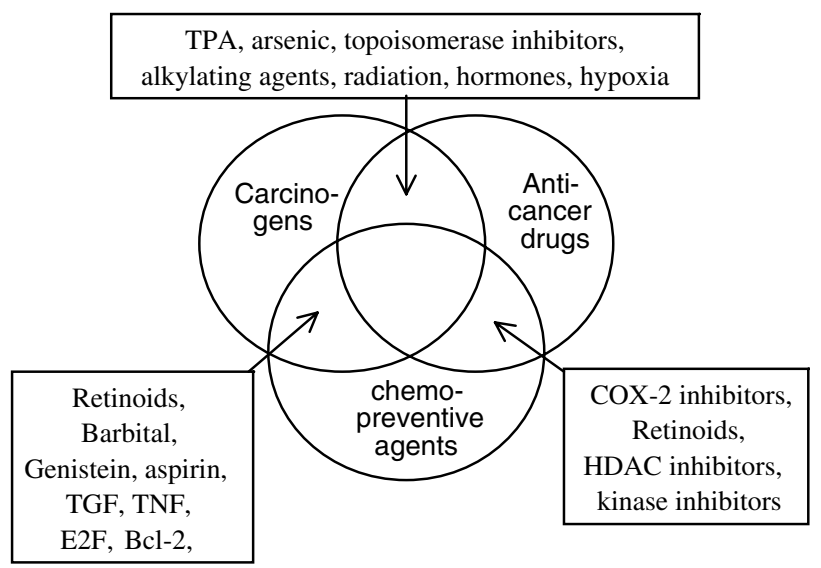

Figure 1 Anticancer drugs, carcinogens and chemopreventive agents overlap. The same agent (arsenic, TPA, alkylating agents, radiation, topoisomerase inhibitors) can cause and treat cancer. Similarly, chemopreventive agents can cause cancer in one setting and prevent it in other setting. Some genes (e.g., E2F) are both oncogenes and tumor suppressors. Certain hormones can prevent, cause and treat cancers

resistance (e.g., detoxifying enzymes, drug pumps ${ }^{43}$ ) and envision that the cytotoxic activity of carcinogens is the driving force for 'accumulation of mutations in oncogenes and tumor suppressors'. (For brevity, the term 'oncogenic mutations' includes both genetic and epigenetic alterations.) Similarly, by inhibiting proliferation and causing apoptosis, cytotoxic anticancer drugs and chemopreventive agents can select for oncogenic resistance, thus driving tumor progression. While therapy-induced killing of cancer cells results in therapeutic response and cancer remission, preferential killing of drugsensitive cancer cells simultaneously selects for resistance that may be accompanied by tumor progression.

\section{Two Types of Resistance to Cytotoxic Agents}

Resistance to cytotoxic agents can be divided into nononcogenic and oncogenic. Nononcogenic resistance includes expression of drug transporters, metabolism of cytotoxic agents and mutations of targets. The resistance is due to prevention and repair of the damage caused by cytotoxic agents. For example, the enzyme O6-methylguanine-DNA methyltransferase (MGMT) repairs alkylation of DNA caused by alkylating agents. ${ }^{10}$ Overexpression of MGMT reduces the risk of carcinogenesis. ${ }^{44,45}$ Therefore, MGMT-deficient cells may preferentially undergo transformation. In turn, low levels of MGMT render cancer cells vulnerable to DNA-damaging drugs and can be exploited for therapy. ${ }^{46}$ The line between nononcogenic and oncogenic resistance can be blurred. For example, amplification of drug target, if the target is an oncogenic kinase, can confirm both nononcogenic and oncogenic resistance. In oncogenic resistance, a cell may ignore the damage. Although cytotoxic agent interacts with its target, downstream pathways of apoptosis and/or growth arrest are blocked (oncogenic resistance). For instance, despite DNA damage, a cell that overexpresses oncoproteins (e.g., ErbB) or lacks tumor suppressors (p53, Rb, p16) continues to proliferate. ${ }^{42,47,48}$ Inhibitors of apoptosis (clAP-1,

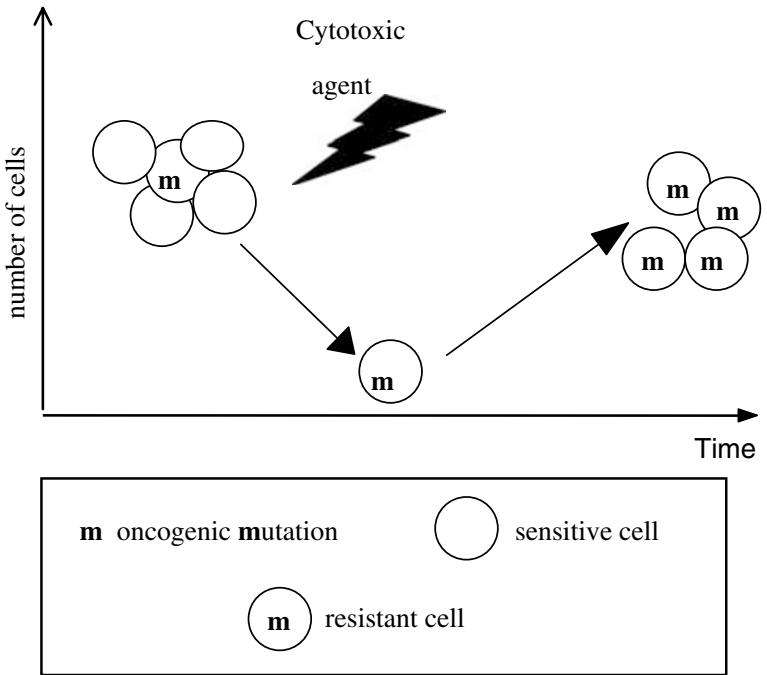

Figure 2 Selection for resistance in carcinogenesis and cancer therapy. Cytotoxic agent inhibits proliferation and/or survival of sensitive cells. Cytotoxic carcinoagent (carcinogen or anticancer drug) selects for resistant cells with mutations $(m)$. This is the selection step (from sensitivity to resistance). Multiple steps can follow, as shown in Figure 3

clAP-2, XIAP, survivin) and oncoproteins (Bcl-2, BclxL, Ras, MEK, Akt, Bcr-Abl) and especially the Akt-TOR pathway can block apoptosis, rendering cancer cells resistant to chemotherapy. ${ }^{1,42,49-55}$ In other words, oncogenic resistance results from alteration in regulation of cell cycle and apoptosis and is associated with the resistance to physiological inhibitors. The main feature of oncogenic resistance is oncogenic translation of ambivalent signaling: namely, due to mutations in oncogenes and tumor suppressors, ambivalent signals (which can cause either growth arrest, proliferation, apoptosis or differentiation) are translated as mitogenic and/or antiapoptotic.

Disabled apoptosis can be linked to genomic instabilities, which are engaged in a positive amplification loop. ${ }^{56}$ During tumor progression, cancer cells accumulate alterations (genetic and epigenetic) in oncogenes and tumor suppressors. ${ }^{57}$ Genetic instability and mutagenic agents provide mutation repertoire. ${ }^{7,8}$ But what is the driving force for accumulation of mutations? Conditions (agents) that restrict proliferation and survival of cells lacking mutations select for adaptive mutations that confirm resistance to these agents (Figure 2). Some carcinogens (e.g., radiation) also cause mutations, thus accelerating selection for carcinogen resistance. But many carcinogens and tumor promoters (nickel, arsenic, TPA) and carcinogenic environments (high cell density, hypoxia, inflammation, TGF- $\beta$ ) are not mutagenic. What most carcinogens and tumor promoters have in common is cytotoxicity against certain normal cells, thus selecting for oncogenic mutations that confirm resistance (Figure 2). Similarly, by killing drug-sensitive cells, anticancer drugs select for cells with mutations that confirm resistance. In other words, the driving force is the cytotoxicity of anticancer drugs. Although drug resistance is traditionally divided into intrinsic and acquired, both types of resistance are actually acquired (Figure 3). Intrinsic resistance is acquired during carcinogenesis and before therapy. 

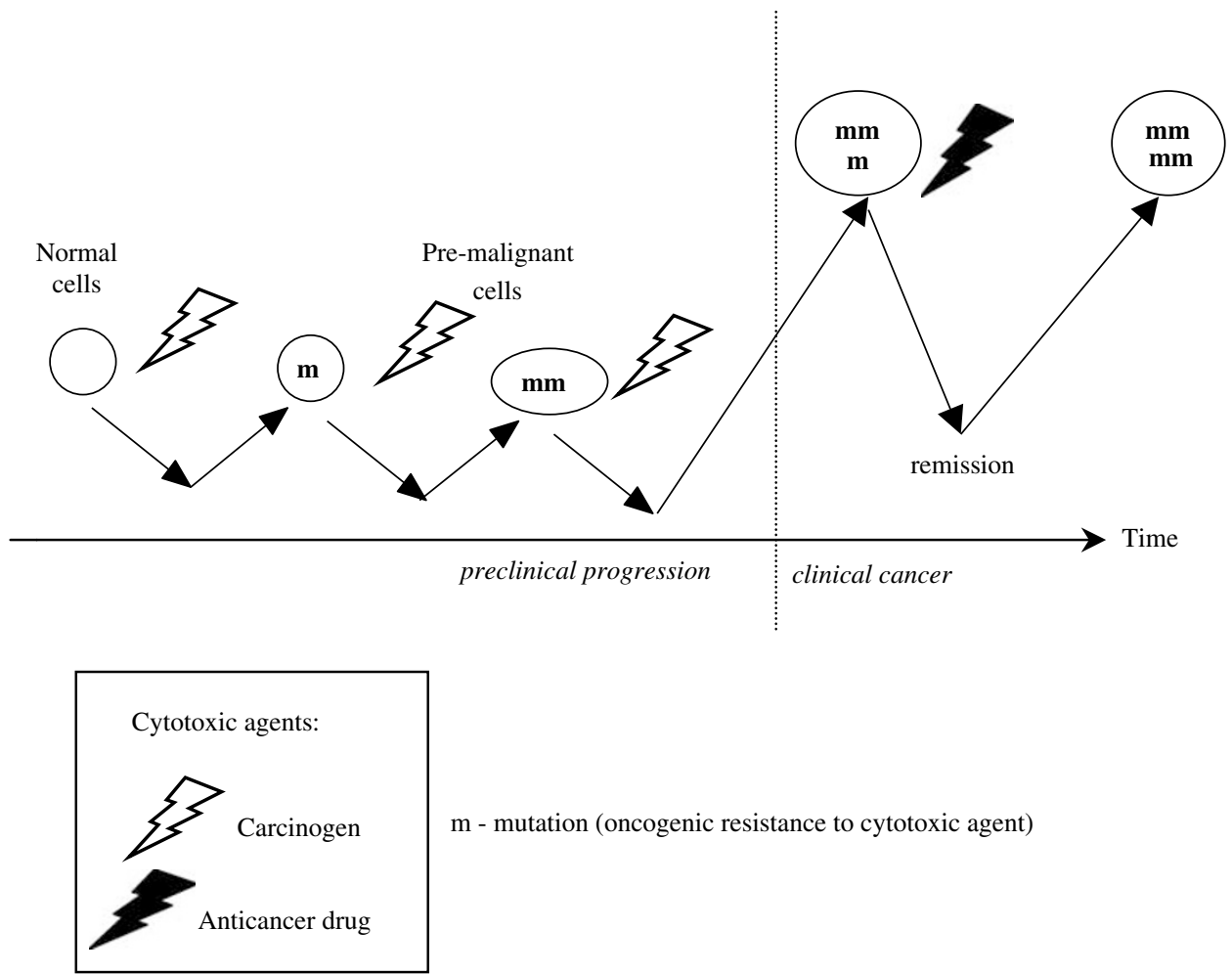

Figure 3 Multistep selection driven by carcinoagents (cytotoxic carcinogens and anticancer drugs). Growth-limiting conditions such as cytotoxic carcinogens can select for resistant $(\mathrm{m})$ cells. A multistep selection both limits and drives carcinogenesis. ${ }^{8,57}$ Carcinogens and tumor promoters inhibit proliferation and/or survival of normal cells selecting for oncogenic mutations $(\mathrm{m}, \mathrm{mm})$. Accumulation of mutations results in cancer. Anticancer drugs further promote tumor progression. Under cytotoxic pressure, cell population can either become extinct (effective cancer therapy) or acquire further resistance due to mutations (tumor progression). From an initial selective step caused by carcinogens through selection steps caused by self-inflicted conditions to selection for drug resistance caused by anticancer drugs, cells acquire oncogenic resistance

\section{Carcinogens (tumor promoters) select for resistance}

It is generally assumed that carcinogens stimulate cell proliferation and block differentiation, because proliferation and dedifferentiation are common characteristics of cancer cells. In contrast to this assumption, carcinogens (e.g., DNAdamaging agents and phorbol ester) inhibit proliferation and induce differentiation. Carcinogenic factors are restrictive (for normal cells) not permissive. While inhibiting proliferation of normal cells, carcinogens do not inhibit (or even stimulate) premalignant cells: namely, cells with oncogenic mutations (see Wille et al. ${ }^{58}$ ). For example, the TPA tumor promoter is cytostatic in certain normal cells. ${ }^{59-61}$ Loss of $\mathrm{Rb}$, overexpression of c-myc, and other oncogenic changes can render cells resistant to TPA. ${ }^{62}$ Then, TPA inhibits normal epithelial cells but their malignant counterparts, selectively favoring their proliferation. ${ }^{63}$

The same alterations that render cells insensitive to TPA also render them insensitive to $\mathrm{TGF}-\beta$, an endogenous cytostatic agent for normal epithelial cells. TGF- $\beta$ inhibits proliferation of normal cells but not malignant cells. ${ }^{64,65}$ And, finally, TGF- $\beta$ stimulates growth and metastasis of the most aggressive late-stage cancers. Whereas TGF- $\beta$ inhibits the formation of benign skin tumors, it enhances the progression to invasive spindle carcinomas. ${ }^{66}$ The final stages of carcinogenic progression may specifically involve changes that radically alter the cellular interpretation of the TGF- $\beta$ signal. ${ }^{64,67}$

Similarly, the tobacco smoke and other DNA-damaging carcinogens inhibit growth of normal cells but not cells with oncogenic mutations (e.g., mutant p53). ${ }^{60,63,68-70}$ In cells with mutant p53, low doses of DNA-damaging carcinogens may not cause growth arrest. While inhibiting the proliferation of normal bronchial epithelial cells, the tobacco smoke may not affect lung cancer cells. ${ }^{70}$ So, the tobacco smoke not only causes p53 mutations but also inhibits proliferation of normal cells, thus selecting cells with p53 mutations. ${ }^{71}$ Agents that simultaneously induce mutations and select for these mutations may be especially carcinogenic. For example, human skin contains clonal patches of p53-mutated keratinocytes. In addition to being a mutagen, sunlight may favor the clonal expansion of p53-mutated cells. ${ }^{72} \mathrm{UV}$ is an ambivalent (both cytotoxic and mitogenic) signal, based on the induction of early-response genes and proto-oncogenes such as jun and fos. UV light is preferentially cytotoxic to normal cells, thus driving skin carcinogenesis. ${ }^{73}$

Mesothelioma cells are resistant to the cytotoxicity of asbestos, a carcinogen that causes mesothelioma. ${ }^{69}$ Cytotoxicity caused by cadmium selects alveolar epithelial cells for apoptosis avoidance. ${ }^{74}$ Also, aflatoxin, which causes hepatocarcinoma, is cytotoxic to normal liver but not tumor cells. ${ }^{68}$ The essence of tumor promoters (including DNA-damaging 
carcinogens) is that they inhibit proliferation of normal cells, thus selecting cells that can proliferate in such a carcinogenic environment. In other words, carcinogens select for cells with oncogenic mutations because oncogenic mutations render cells resistant to growth arrest and apoptosis caused by these carcinogens.

\section{Therapy-induced cancer and tumor progression}

Typically, anticancer drugs are toxic to both cancer and normal cells, causing therapeutic and side effects, respectively. We can predict that cytotoxicity to cancer cells may cause tumor progression, whereas the cytotoxicity to normal cells may result in secondary tumors. Specifically:

\section{Tumor progression}

By selecting for oncogenic resistance, anticancer drugs may drive tumor progression. In vitro, chemotherapy can increase oncogenic characteristics, such as invasiveness and metastasis. ${ }^{75-79}$ Immortalized endocervical cells selected for resistance to cisplatin are malignantly transformed. ${ }^{80}$

Testicular cancer and childhood leukemia cells are apoptosis-prone. Therefore, chemotherapy preferentially kills such cancer and leukemia cells causing remissions and even curative outcomes. Yet, if the disease relapses, it becomes resistant to chemotherapy, because all sensitive cells have been selectively eliminated. As another example, hormonal therapy of prostate cancer is very effective, but eventually selects for hormone independence. Even further, inhibitors of androgen receptor may stimulate rather than inhibit resistant cancer cell. ${ }^{81}$ In differentiated thyroid cancer, therapy with $\mathrm{TSH}$ and radioactive iodine causes high response and remission rate. Following remission, thyroid cancer may relapse as dedifferentiated carcinoma, which is highly resistant to chemotherapy. ${ }^{82}$ As another example, Gleevec induces remissions in Bcr-Abl-positive leukemia. By killing sensitive leukemia cells, Gleevec selects for cells with additional oncogenic alterations that may be responsible for disease progression in relapse. ${ }^{83-86}$ Similarly, antiangiogenic therapy may select for hypoxia-resistant cancers. ${ }^{87}$

When anticancer drugs cause therapeutic response, they simultaneously select for drug resistance due to elimination of drug-sensitive cancer cells (Figures 2 and 3). Yet, therapy of most common cancers is not sufficiently effective, thus causing neither remissions nor tumor progression. To cause tumor progression, a therapy must be near-curative. ${ }^{87}$

\section{Secondary cancers}

It is believed that normal cells do not acquire resistance to anticancer drugs because resistant normal cells do not emerge. Thus, patients do not become tolerant to chemotherapy over time.

Yet, normal cells can acquire resistance. Just they are not normal anymore: resistance to anticancer drugs is manifested as therapy-induced cancers. By selecting for resistance and for genetic instability, anticancer drugs cause secondary cancers. In comparison with tumor promoters, anticancer drugs are more cytotoxic, because they are aimed at cancer cells and used at maximally tolerated doses. Therefore, normal cells do not easily acquire resistance to anticancer drugs. In other words, they rarely become malignant following chemotherapy, but if they do, such chemotherapy-caused cancers are especially resistant to further therapy. ${ }^{88-91}$ Secondary leukemia is often inhibited apoptotic response. ${ }^{92}$ Chemotherapy-related leukemias account for $10-20 \%$ of all acute myeloid leukemia (AML) cases and are resistant. ${ }^{88}$ Secondary tumors include brain tumors, leukemia, breast cancer, thyroid cancer, bone and soft-tissue sarcoma. ${ }^{93}$ Radiation, alkylating agents and topoisomerase II inhibitors are most common causes for secondary tumors. ${ }^{89-94}$ Leukemias induced by alkylating agents usually follow a long period of latency and present as myelodysplasia with unbalanced chromosomal aberrations such as deletions of chromosome 13, 5 or 7. DNA topoisomerase II inhibitors cause leukemias with translocations of the MLL gene at chromosome band $11 q 23$ or, less often, $t(8 ; 21), t(3 ; 21)$, inv(16), $t(8 ; 16), t(15 ; 17)$ or $t(9 ; 22)$. Between 2 and $12 \%$ of patients who receive topoisomerase inhibitors have developed t-AML. ${ }^{28,95}$

\section{Carcinogens as anticancer drugs}

Arsenic and phorbol ester (TPA) exemplify carcinogens turned into anticancer drugs. Still this is considered as an exception. The prevailing notion is that anticancer drugs and carcinogens are opposites. Likewise, there is no search for new anticancer drugs among carcinogens. This may explain a reluctance to introduce the classic tumor promoter TPA to the clinic. In clinical trials, TPA has demonstrated effectiveness in therapy of drug-resistant leukemia. ${ }^{24}$

It is a misconception that an agent that causes cancer cannot be used as anticancer drug. In reality, alkylating and other DNA-damaging drugs, radiation, hormones and antihormones are all carcinogenic. There are startling examples. Alcohol is one of the causes of hepatocarcinomas. On the other hand, percutaneous ethanol injections are used for therapy of hepatocarcinomas. ${ }^{96}$ Furthermore, low ethanol concentrations $(1 \mathrm{mmol})$ inhibit cell proliferation and increase apoptosis more strongly in hepatocarcinoma cells than in normal hepatocytes. ${ }^{97}$ Ethanol injection can lengthen survival in patients with hepatocellular carcinoma. ${ }^{98}$

Carcinogens are cytotoxic to certain cancer cells. Cancer cells are resistant to agents that cause this particular cancer. More than 65 years ago, it was noted that tumors that are caused by alkylating carcinogens are resistant to alkylating drugs. ${ }^{41}$ Yet, alkylating agents may be effective against some cancers such as testicular cancer and childhood leukemia. DNA-damaging drugs, which are effective in testicular cancer and leukemias, are not necessarily effective in secondary cancers. Similarly, cancer that has been promoted by TPA will be probably resistant to therapy with TPA. But leukemia cells that are resistant to DNA-damaging agents may retain sensitivity to TPA. ${ }^{24}$ Also, secondary cancers caused by chemotherapy are expected to be resistant to DNA-damaging drugs. But they may be sensitive to Gleevec. ${ }^{99}$

As shown in Figure 4, if agent A causes particular cancer, then agent $A$ cannot 'cure' the same cancer. Thus, a futile therapy can be avoided. Cancer cells are still sensitive (or hypersensitive) to different classes of cytotoxic agents (agent 
$B)$. In contrast, if agent $B$ had caused cancer, then agent $A$ (Figure 4b) may be used for therapy. A carcinogen turns into an anticancer drug and vice versa (Figure 4).

It is important to emphasize that overlap between carcinogens and anticancer drugs is not accidental. Any agent that is cytotoxic can cause cancer and can be used for cancer therapy, precisely because it is cytotoxic. In theory, DMBA, okadaic acid and aflatoxin, for instance, may be developed as anticancer drugs. Okadaic acid, an inhibitor of serine/ threonine protein phosphatases 1 and $2 \mathrm{~A}$, is a tumor promoter. Okadaic acid also induces apoptosis in most tumor cell lines and could be considered as an anticancer drug. Furthermore, cells with mutations in Ras are more sensitive to okadaic acid ${ }^{100,101}$ implying its potentially chemopreventive properties. As another example, many effects of the carcinogen benzo(a)pyrene dihydrodiol epoxide (BPDE) and anticancer drug camptothecin (CPT) are similar. Low doses (50$100 \mathrm{nM}$ ) of BPDE activate Chk1 causing a reversible S-phase arrest, while higher doses cause permanent S-phase arrest and cell death. ${ }^{102}$ The cytotoxicity of CPT is also S-phase specific and CHK1-regulated S-phase checkpoint response protected cells from CPT-induced killing. ${ }^{103}$ Can BPDE be used therapeutically as an S-phase-specific drug that induces a reversible Chk-1-dependent arrest? And, if ethanol can be used for the therapy of liver cancer, why not to consider a one step further: cytotoxic agents from the tobacco smoke may restrain growth of certain types of lung cancer cells in some nonsmokers. This example is merely hypothetical.

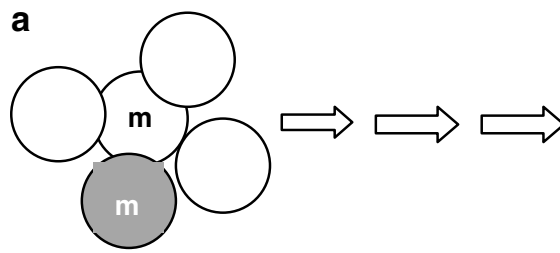

$$
\text { Agent A }
$$

carcinogenesis

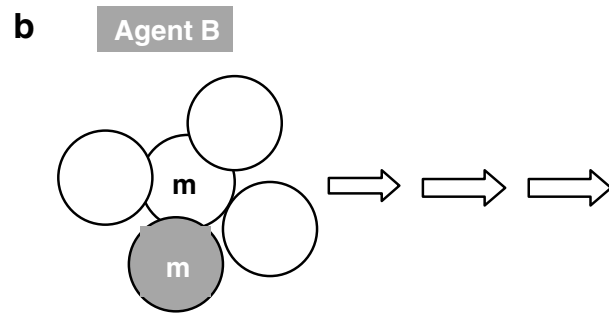

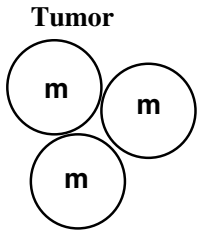

Agent B cancer therapy

\section{Agent A}

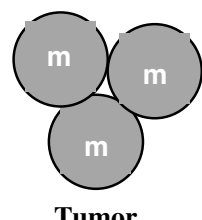

Tumor

Figure 4 The role reversal of anticancer drugs and carcinogens. (a) Cytotoxic agent $A$ is a carcinogen because it inhibits proliferation of normal cells, selecting for cells with mutations $(m)$. Cancer cells are still sensitive to agent $B$. In this scenario, mutations that are selected by agent $A$ render cells resistant to agent $A$ and sensitive to agent $B$. (b) Agent $B$ is a carcinogen because it inhibits proliferation of normal cells, selecting cells with distinct types of mutations $(m)$. Accumulation of mutations results in cancer that is resistant to agent $\mathrm{B}$. Cytotoxic agent $A$, which at low doses causes cancer, inhibits proliferation of cancer cells that are caused by agent $B$. Cancer cells are sensitive to agent $A$ and resistant to agent $B$

\section{Empirical chemoprevention: a double-edge sword}

It is often emphasized that chemopreventive agents can inhibit oncogenic pathways, inhibit growth and induce apoptosis in cancer cells. Then, what is the difference between anticancer and chemopreventive agents? Furthermore, if agents are cytotoxic to cancer cells, then, like chemotherapy, they must cause severe side effects. Finally, cancer cells are relatively resistant to apoptosis. Therefore, if an agent can induce apoptosis even in cancer cells, then it can kill normal cells too. If so, side effects would be inevitable. Conventional chemopreventive agents are expected to be administered long-term to healthy individuals. As emphasized, even minor adverse side effects would be unacceptable. ${ }^{104}$ Actually, to cause apoptosis in cancer cells in vitro, potential chemopreventive agents are used at intolerably high concentrations. For example, chemopreventive agents from the green tea induce apoptosis and growth arrest in vitro at doses that are not achievable in humans via tea consumption. ${ }^{105}$ Perhaps, dietary chemopreventive agents, at physiological concentrations, do not cause apoptosis in cancer cells.

Second problem is that chemopreventive agents and carcinogens overlap (Figure 1). As any cytotoxic agents, chemopreventive agents may select for oncogenic resistance. If some premalignant cells are resistant to chemopreventive agent (due to additional oncogenic mutations), then this chemopreventive agent will select oncogenic cells, thus driving tumor progression. Moreover, the same agent may be chemopreventive at early stages, but may promote cancer later in tumor progression. For example, TGF- $\beta$ and retinoic acid inhibit the formation of benign tumors, but enhance progression to carcinomas. $^{32,66}$

\section{Selective chemoprevention: exploiting oncogene- addiction}

Unlike anticancer drugs, chemopreventive agents should not necessarily affect advanced cancer cells. Chemopreventive agents should be selectively cytotoxic to premalignant cells. A chemopreventive agent must provide selective disadvantage (by causing apoptosis, growth arrest or differentiation) to cells with a single oncogenic alteration (Figure 5). But is this

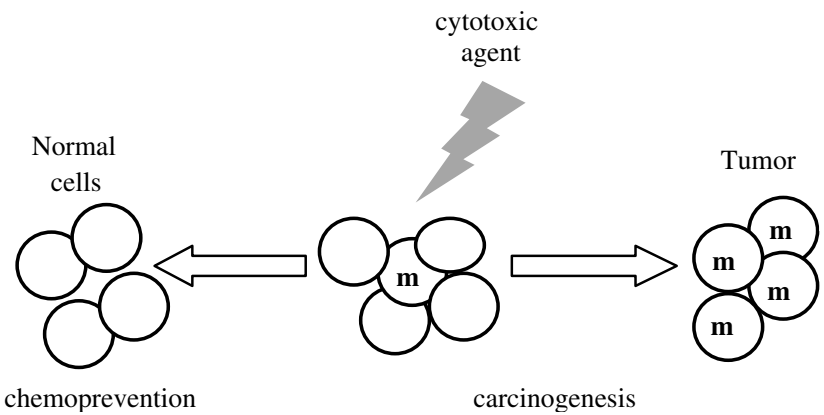

Figure 5 Chemoprevention versus tumor promotion. Cytotoxic agent can select either for or against mutant cells. A mutation can confirm resistance to one agent (carcinogen) and sensitivity to another (chemopreventive agent). In theory, cells bearing oncogenic mutations may be vulnerable to certain agents (chemopreventive agents) 
possible? Carcinogens select for cells with an oncogenic mutation, precisely because such a mutation renders cells resistant. How may chemopreventive agents selectively suppress such resistant cells? In other words, why would carcinogen-resistant cells be hypersensitive to other agents? First, while rendering cells resistant to one condition, an oncogenic mutation can cause a collateral sensitivity to another condition. c-myc renders cells resistant to growth arrest but sensitive to apoptosis, whereas Ras can prevent apoptosis but favors cell senescence. . $^{3,48,106,107}$

Similarly, mutations can render cells resistant to one agent (carcinogen) but sensitive to another (chemopreventive) agent. As the simplest example, cells with Bcr-Abl are resistant to DNA-damaging drugs but are very sensitive to inhibitors of Bcr-Abl. ${ }^{108}$ Also, p53 disruption sensitizes certain cells to DNA-damaging agents, but renders these cells resistant to the antimetabolite 5-fluorouracil. ${ }^{109}$ As another example, activation of S-phase checkpoint and induction of E2F1 render cancer cells hypersensitive to lapachone. ${ }^{110}$

Anticancer drugs that selectively suppress cells with a single oncoprotein are chemopreventive by definition. For example, Gleevec (imatinib), an inhibitor of Bcr-Abl, is selectively toxic to cells that express Bcr-Abl. ${ }^{111,112}$ Since Gleevec selectively kills cells with Bcr-Abl, Gleevec is actually a mechanism-based chemopreventive agent for chronic myeloid leukemia (CML), which is caused by Bcr-Abl. Furthermore, there is no need for continuous administration of mechanism-based chemopreventive agents. In brief courses, Gleevec will eliminate rare cells that acquire BcrAbl. (Of course, to use Gleevec as chemopreventive agent, it will be necessary to identify people at high risk for CML.) BCRABL fusion transcripts can be detected by RT-PCR in the leukocytes of some healthy individuals. ${ }^{113}$ For $\mathrm{CML}$, an early therapy is actually a mechanism-based chemoprevention. This suggests therapy with Gleevec in newly diagnosed CML before additional mutations occur. Similarly, inhibitors of the EGF receptor and ErbB2 will be more effective in premalignant cells than in advanced cancer with multiple mutations. In mice, inhibitors of the EGF receptor prevented breast cancer in ErbB2 transgenic mice ${ }^{114}$ and polyps. ${ }^{115}$

Especially at early stages of carcinogenesis, when premalignant cells depend on one sole oncogene, inactivation of such an oncogene can result in apoptosis (oncogeneaddiction). ${ }^{116,117}$ Oncogene-addiction is the Achilles heel of oncogenic resistance. Yet, further tumor progression renders cells oncogene-independent due to acquiring additional mutations. For example, c-myc-induced tumorigenesis is initially c-myc-dependent but can progress to c-myc-independent phase. ${ }^{118-120}$

\section{Protective chemoprevention: induction of nononcogenic resistance}

Carcinogenesis is selection for oncogenic resistance to carcinogens. In contrast, acquiring nononcogenic resistance may stop further tumor progression. In theory, by acquiring nononcogenic resistance, a cell avoids selective pressure without becoming oncogenic. For example, nononcogenic resistance might prevent the development of cancer (there- fore, primary cancer cells are usually Pgp-negative). In colorectal carcinogenesis, Pgp is typically expressed in the adenoma stage, protecting the epithelium against further environmentally induced damage. ${ }^{121}$ This may explain why only $5 \%$ of adenomas actually progress to cancer ${ }^{121}$ and why untreated cancers are usually Pgp-negative. As another example, the DNA repair protein MGMT prevents carcinogen-induced conversion of benign tumors into malignant tumors. $^{122}$ In other words, by conferring nononcogenic resistance, MGMT abolishes selective pressure. MGMT is often silenced in tumors and therefore they are sensitive to alkylating drugs. ${ }^{9}$ Reactivation of MGMT renders cancer cells resistant to chemotherapy. ${ }^{123}$

Similarly, abrogation of cytotoxic effects of aflatoxin prevents carcinogenesis in rat liver. ${ }^{124}$ Even oncogenes can prevent cancer in certain circumstances. ${ }^{125} \mathrm{Bcl}-2$ retards ultraviolet- and chemical-induced tumorigenesis. ${ }^{73}$ Perhaps, by causing resistance to apoptosis, $\mathrm{Bcl}-2$ (in certain conditions) prevents selection for additional oncogenic mutations. (Of course, in most conditions, Bcl-2 accelerates carcinogenesis.) Pharmacological agents also can render cells nononcogenically resistant, thus preventing carcinogenesis. $^{126,127}$

\section{Cancer therapy: selective drugs and selective combinations}

As we discussed, selection for resistance to carcinogens and anticancer drugs are essentially identical processes. There are several consequences. First, anticancer drugs are carcinogenic and may further drive tumor progression. In order to occur, however, tumor progression must be preceded by tumor regression (remission) (Figure 3). Second, carcinogenic agents may become new anticancer drugs. Third, 'carcinogenic history' of a particular cancer may indicate which drugs will be ineffective. For example, cancer caused by arsenic will not be sensitive to arsenic-based therapy, and doxorubicin (DOX)-induced secondary cancer will be probably insensitive to standard chemotherapy. Thus, patients may avoid futile therapy.

In rare cancers that depend on a single oncogenic mutation (e.g., Bcr-Abl in CML and the EGF receptor with activating mutation in lung cancer), drugs that inhibit such oncogenes can selectively kill leukemia and cancer cells. ${ }^{128-131}$ Technically, the therapy with an agent that targets a single oncogenic alteration and selects against cells with such mutations is 'chemoprevention' (as defined herein). In other words, it is chemoprevention that is used as cancer therapy. In general, however, cancer cells have multiple mutations and are intrinsically resistant to growth arrest and apoptosis. It seems easier to kill normal cells than cancer cells. Furthermore, following chemotherapy, cancer cells can acquire nononcogenic resistance (e.g., MRP). How then can anticancer drugs be selectively cytotoxic to such resistant cells? It is possible to exploit resistance using antagonistic drug combinations. ${ }^{132}$ For example, a combination of apoptosis-inducing agents and caspase inhibitors is clearly antagonistic. But these combinations can selectively kill cancer cells that are 'resistant' to inhibitors of caspases. ${ }^{133-135}$ This will allow one to use 
apoptosis-inducing agents selectively. As another example, pretreatment with DOX antagonizes cytotoxicity of paclitaxel (PTX). Low concentrations of DOX cause G2 arrest in normal cells but not in cancer cells with mutant p53 (oncogenic resistance) and with MRP (nononcogenic resistance). ${ }^{132}$ While DOX protects nonresistant normal cells, PTX kills only DOX-resistant cells. In theory, the combination DOX + PTX will eventually select for resistance. Resistance to this combination could be due to re-acquiring sensitivity to DOX. Although selection for resistance is not avoidable, it can be exploited for therapy.

\section{Unifying model}

The common feature of carcinogenesis, therapy and chemoprevention is selection for resistance due to suppression of sensitive cells. Whether normal or malignant cells (or cells at different stages of tumor progression) are more sensitive determines the 'direction' of the process: carcinogenesis versus therapy/prevention (Figure 5).

For example, DNA-damaging agents such as etoposide (an inhibitor of topoisomerase II) can cure testicular cancer. ${ }^{136}$ Topoisomerase II inhibitors are also very cytotoxic to normal epithelial and bone marrow cells. Also, they can induce the translocation of Bcr-Abl (t9;22) in bone marrow cells. ${ }^{95}$ Most importantly, Bcr-Abl-expressing cells are resistant to apoptosis caused by DNA-damaging drugs. ${ }^{5,137}$ Therefore, continuous exposure to DNA-damaging agents (as well as endogenous cytotoxic agents) may cause selective expansion of Bcr-Abl-expressing cells, eventually resulting in leukemia (Figure 6a). At this point, it would be futile to treat such leukemia by DNA-damaging drugs, even though they are effective in primary leukemias and testicular cancer. Instead, the Achilles heel is the dependence on Bcr-Abl. This could be exploited for therapy (and potentially for chemoprevention). The Bcr-Abl kinase inhibitor Gleevec is selectively cytotoxic to $\mathrm{Bcr}-\mathrm{Abl}$-expressing cells, thus causing remission (Figure $6 \mathrm{~b}$ ). On the other hand, it selects for resistant leukemic clones.
Once resistance occurs, opposite strategies may be used in sequence. One striking example is the reversion from blast to chronic phase of leukemia after withdrawal of Gleevec. ${ }^{138}$ Finally and remarkably, Gleevec also may cause cancer, acting as a carcinogen. Gleevec causes side effects due to inhibition of certain normal cells that are dependent on c-Kit and PDGF. ${ }^{139,140}$ Then (like any agent that is toxic to certain normal cells), it may select for oncogenic resistance. In fact, the development of squamous cell carcinoma of the skin ${ }^{141}$ and c-Kit-expressing small-cell lung cancer ${ }^{142}$ has been reported following therapy of CML with Gleevec.

Given that carcinogenic and therapeutic effects are determined by cellular context, the term carcinoagents can include carcinogens, physiological regulators and anticancer agents. Carcinoagents are ambivalent. They suppress one type of cells while promoting survival of another type. Such suppression could be due to apoptosis, nonapoptotic (slow) cell death, cell senescence, differentiation and reversible cycle arrest. Although we cannot discuss this in detail, apoptosis is considered a goal of cancer therapy, the preferential outcome of therapy. ${ }^{4,104,135,143-150}$ This suggestion is based on the observation that curable malignancies are usually apoptosis-prone. Returning to the beginning of this article, the question is how can apoptosis be a goal of cancer therapy, if apoptosis avoidance is a hallmark of cancer. First, cancer cells can be resistant to DNA damage but sensitive to kinase inhibitors and vice versa, depending on the carcinogenic history (Figures 4 and 6). Second, cancer arises from apoptosis-prone tissues. For example, cancer does not originate from arterial smooth muscle cells, which are extremely resistant to apoptosis. In contrast, inefficient hematopoiesis due to extensive apoptosis of defective cells leads to leukemia. Apoptosis-prone tissues become malignant because they are apoptosis prone and/or controlled by restrictive regulators. For example, normal breast and prostate cells are tightly controlled by growth factors and hormones and are apoptosis-prone. Like exogenous carcinoagents, physiological restrictions drive carcinogenesis.

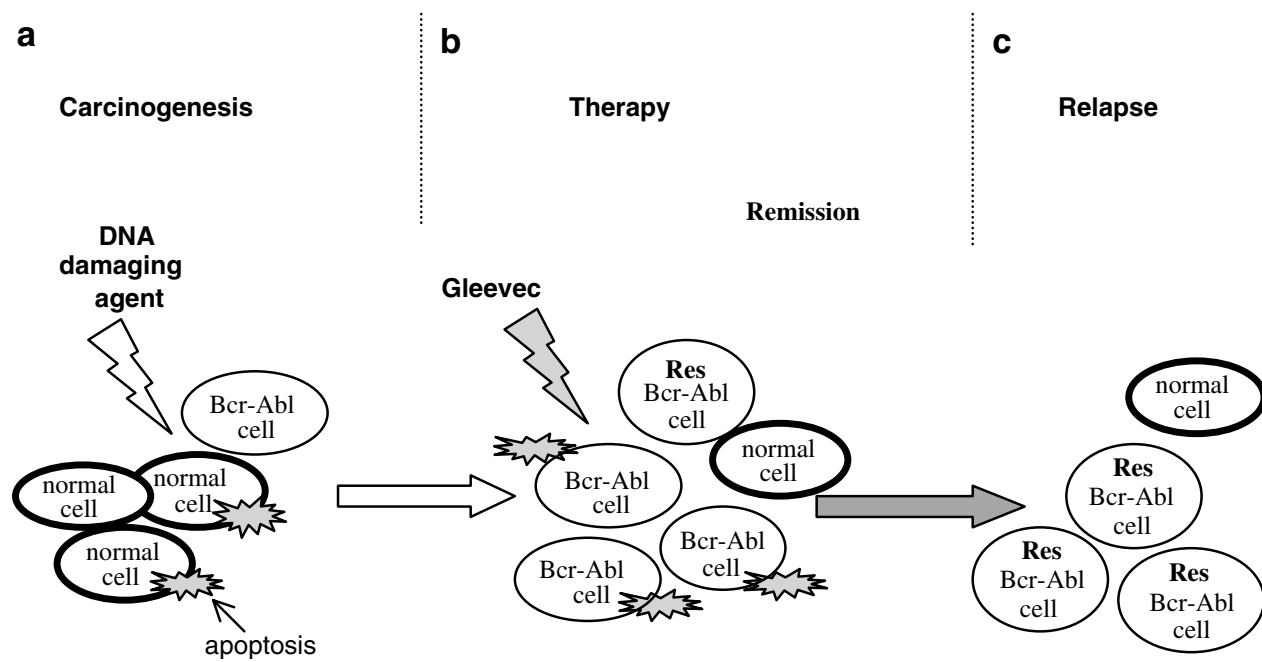

Figure 6 From carcinogenesis to therapy. (a) Carcinogenesis. By inducing apoptosis in normal hematopoietic cells, DNA-damaging agents select for cells with Bcr-Abl. (b) Therapy. By inducing apoptosis in Bcr-Abl-expressing cells, Gleevec selects for normal hematopoietic cells, thus causing remission. (c) Progression. By sparing BcrAbl-expressing cells having additional oncogenic mutations (Res-Bcr-Abl), Gleevec selects for resistant leukemia cells and disease progression 
Later, by invading and outgrowing their blood supply, tumors do not need any exogenous carcinogens to drive further selection. A tumor itself creates carcinogenic conditions to select for resistance. Thus, cancer cells become resistant compared with their parental normal cells but not necessarily compared with arterial SMC and dermal fibroblasts, for instance. This will be a topic for a future review.

\section{Future directions}

As announced by Andrew von Eschenbach, ' $\mathrm{NCl}$ sets goal of eliminating suffering and death due to cancer by 2015'. ${ }^{151}$ To cure and prevent cancer, therapeutic and chemopreventive agents and their combinations can be selectively cytotoxic to cancer and premalignant cells while sparing normal cells. Three potential strategies, aimed at cancer- and tissuespecific targets and selective combinations aimed at universal targets with protection of normal cells, can control cancer. ${ }^{152}$ Yet, any effective therapy is limited by selection for resistance and potential tumor promotion. Therefore, opposite therapeutic strategies should be used in sequence. ${ }^{152}$

To control cancer, it is important to realize, as discussed here, that carcinogenesis and cancer therapy are identical processes and there is little difference between agents that promote and halt cancer. Similarities between carcinogens and anticancer drugs indicate that carcinogens offer a potential source of new anticancer drugs to cancers induced by other carcinogens (specifically, the type of therapy must be selected on the understanding that the inducer cannot also be the therapy). The term carcinoagents emphasizes the dual nature of cytotoxic agents. Carcinoagents include not only carcinogens and drugs but also physiological restrictive signaling molecules such as TGF- $\beta$ and immunological suppressors, for instance. All could be used to control cancer.

\section{References}

1. Reed JC (1999) Mechanisms of apoptosis avoidance in cancer. Curr. Opin. Oncol. 11: 68-75

2. Hanahan D and Weinberg RA (2000) The hallmarks of cancer. Cell 100: 57-70

3. Evan Gl and Vousden KH (2001) Proliferation, cell cycle and apoptosis in cancer. Nature 342-348

4. Johnstone RW, Ruefli AA and Lowe SW (2002) Apoptosis: a link between cancer genetics and chemotherapy. Cell 108: 153-164

5. Hickman JA (2002) Apoptosis and tumorigenesis. Curr. Opin. Genet. Dev. 12: 1

6. Green DR and Evan GI (2002) A matter of life and death. Cancer Cell 1: $19-30$

7. Lengauer C, Kinzler KW and Vogelstein B (1998) Genetic instabilities in human cancers. Nature 396: 643-649

8. Cahill DP, Kinzler KW, Vogelstein B and Lengauer C (1999) Genetic instability and darwinian selection in tumours. Trends Cell Biol. 9: M57-M60

9. Esteller M, Garcia-Foncillas J, Andion E, Goodman SN, Hidalgo OF, Vanaclocha V, Baylin SB and Herman JG (2000) Inactivation of the DNArepair gene MGMT and the clinical response of gliomas to alkylating agents. N. Engl. J. Med. 343: 1350-1354

10. Middleton MR and Margison GP (2003) Improvement of chemotherapy efficacy by inactivation of a DNA-repair pathway. Lancet Oncol. 4: 37-44

11. Lawley PD (1995) Alkylation of DNA and its aftermath. BioEssays 17: $561-568$
12. Margison GP and Santibanez-Koref MF (2002) 06-alkylguanine-DNA alkyltransferase: role in carcinogenesis and chemotherapy. BioEssays 24: 255-266

13. Benedict WF, Banerjee A, Gardner A and Jones PA (1977) Induction of morphological transformation in mouse $\mathrm{C} 3 \mathrm{H} / 10 \mathrm{~T} 1 / 2$ clone 8 cells and chromosomal damage in hamster $\mathrm{A}(\mathrm{T} 1) \mathrm{C} 1-3$ cells by cancer chemotherapeutic agents. Cancer Res. 37: 2202-2208

14. Sanderson BJ, Ferguson LR and Denny WA (1996) Mutagenic and carcinogenic properties of platinum-based anticancer drugs. Mutat. Res. 355: $59-70$

15. Williams D (2002) Cancer after nuclear fallout: lessons from the Chernobyl accident. Nat. Rev. Cancer 2: 543-549

16. Pelikan DM, Lion HL, Hermans J and Goslings BM (1997) The role of radioactive iodine in the treatment of advanced differentiated thyroid carcinoma. Clin. Endocrinol. 47: 713-720

17. Senior K (2002) Arsenic: carcinogen or cancer therapy? Drug Discov. Today 7: $156-157$

18. Zhu J, Chen Z, Lallemand-Breitenbach V and de The H (2002) How acute promyelocytic leukaemia revived arsenic. Nat. Rev. Cancer 2: $705-713$

19. Bouchardy C, Verkooijen H, Fioretta G, Sappino A and Vlastos G (2002) Increased risk of malignant mullerian tumor of the uterus among women with breast cancer treated by tamoxifen. J. Clin. Oncol. 20: 4403

20. Curtis RE, Boice JDJ, Shriner DA, Hankey BF and Fraumeni JFJ (1996) Second cancers after adjuvant tamoxifen therapy for breast cancer. J. Natl. Cancer Inst. 88: 824-832

21. Curtis RE, Freedman DM, Sherman ME and Fraumeni JFJ (2004) Risk of malignant mixed mullerian tumors after tamoxifen therapy for breast cancer. J. Natl. Cancer Inst. 96: 70-74

22. Strair RK, Schaar D, Goodell L, Aisner J, Chin KV, Eid J, Senzon R, Cui XX, Han ZT, Knox B, Rabson AB, Chang R and Conney A (2002) Administration of a phorbol ester to patients with hematological malignancies: preliminary results from a phase I clinical trial of 12-0-tetradecanoylphorbol-13-acetate. Clin. Cancer Res. 8: 2512-2518

23. Han ZT, Tong YK, He LM, Zhang Y, Sun JZ, Wang TY, Zhang H, Cui YL, Newmark HL, Conney AH and Chang RL (1998) 12-O-tetradecanoylphorbol13-acetate (TPA)-induced increase in depressed white blood cell counts in patients treated with cytotoxic cancer chemotherapeutic drugs. Proc. Natl. Acad. Sci. USA 95: 5362-5365

24. Han ZT, Zhu XX, Yang RY, Sun JZ, Tian GF, Liu XJ, Cao GS, Newmark HL, Conney AH and Chang RL (1998) Effect of intravenous infusions of 12-Otetradecanoylphorbol-13-acetate (TPA) in patients with myelocytic leukemia: preliminary studies on therapeutic efficacy and toxicity. Proc. Natl. Acad. Sci. USA 95: 5357-5361

25. Zheng X, Chang R, Cui XX, Avila GE, Lee S, Lu YP, Lou YR, Shin WJ, Lin Y, Reuhl K, Newmark H, Rabson A and Conney AH (2004) Inhibitory effect of 12O-tetradecanoylphorbol-13-acetate alone or in combination with all-transretinoic acid on the growth of LNCaP prostate tumors in immunodeficient mice. Cancer Res. 64: 1811-1820

26. Sieber SM (1977) The action of antitumor agents: a double-edged sword? Med. Pediatr. Oncol. 3: 123-131

27. Carli PM, Sgro C, Parchin-Geneste N, Isambert N, Mugneret F, Girodon F and Maynadie M (2000) Increase therapy-related leukemia secondary to breast cancer. Leukemia 14: 1014-1017

28. Leone G, Voso MT, Sica S and Morosetti R and Pagano L (2001) Therapy related leukemias: susceptibility, prevention and treatment. Leuk. Lymphoma 41: $255-276$

29. Sandoval C, Pui CH, Bowman LC, Heaton D, Hurwitz CA, Raimondi SC, Behm FG and Head DR (1993) Secondary acute myeloid leukemia in children previously treated with alkylating agents, intercalating topoisomerase II inhibitors, and irradiation. J. Clin. Oncol. 11: 1039-1045

30. Conney AH (2004) Tailoring cancer chemoprevention regimens to the individual. J. Cell. Biochem. 91: 277-286

31. Yang K, Fan K, Kurihara N, Shinozaki H, Rigas B, Augenlicht L, Kopelovich L, Edelmann W, Kucherlapati R and Lipkin M (2003) Regional response leading to tumorigenesis after sulindac in small and large intestine of mice with Apc mutations. Carcinogenesis 24: 605-611

32. Tennenbaum T, Lowry D, Darwiche N, Morgan DL, Gartsbein M, Hansen L, De Luca LM, Hennings H and Yuspa SH (1998) Topical retinoic acid reduces 
skin papilloma formation but resistant papillomas are at high risk for malignant conversion. Cancer Res. 58: 1435-1443

33. Nayfield SG, Karp JE, Ford LG, Dorr FA and Kramer BS (1991) Potential role of tamoxifen in prevention of breast cancer. J. Natl. Cancer Inst. 83: 1450-1459

34. Pukkala E, Kyyronen P, Sankila R and Holli K (2002) Tamoxifen and toremifene treatment of breast cancer and risk of subsequent endometrial cancer: a population-based case-control study. Int. J. Cancer 100: 337-341

35. Kakizoe T (2003) Chemoprevention of cancer - focusing on clinical trials. Jpn. J. Clin. Oncol. 33: 421-442

36. Baron JA, Cole BF, Mott L, Haile R, Grau M, Church TR, Beck GJ and Greenberg ER (2003) Neoplastic and antineoplastic effects of beta-carotene on colorectal adenoma recurrence: results of a randomized trial. J. Natl. Cancer Inst. 95: 717-722

37. Gescher AJ, Sharma RA and Steward WP (2001) Cancer chemoprevention by dietary constituents: a tale of failure and promise. Lancet Oncol. 2 371-379

38. Hilakivi-Clarke L, Cho E, Onojafe I, Raygada M and Clarke R (1999) Maternal exposure to genistein during pregnancy increases carcinogen-induced mammary tumorigenesis in female rat offspring. Oncol. Rep. 6: 1089-1095

39. Schernhammer ES, Kang JH, Chan AT, Michaud DS, Skinner HG Giovannucci E, Colditz GA and Fuchs CS (2004) A prospective study of aspirin use and the risk of pancreatic cancer in women. J. Natl. Cancer Inst. 96: $22-28$

40. Duffield-Lillico AJ, Slate EH, Reid ME, Turnbull BW, Wilkins PA, Combs GFJ, Park HK, Gross EG, Graham GF, Stratton MS, Marshall JR and Clark LC (2003) Selenium supplementation and secondary prevention of nonmelanoma skin cancer in a randomized trial. J. Natl. Cancer Inst. 95: 1481-1577

41. Haddow A (1938) The influence of carcinogenic substances on sarcomata induced by the same and other compounds. J. Pathol. Bacteriol. 47: $581-591$

42. Vogelstein B and Kinzler KW (2004) Cancer genes and the pathways they control. Nat. Med. 10: 789-799

43. Fojo $T$ and Bates S (2003) Strategies for reversing drug resistance. Oncogene 22: 7512-7523

44. Zaidi NH, Allay E, Ayi TC, Li BF, Dumenco LL, Sy MS and Gerson SL (1995) The immature thymocyte is protected from $\mathrm{N}$-methylnitrosourea-induced lymphoma by the human MGMT-CD2 transgene. Carcinogenesis 16 1047-1053

45. Reese JS, Allay E and Gerson S (2001) Overexpression of human 06alkylguanine DNA alkyltransferase (AGT) prevents MNU induced lymphomas in heterozygous p53 deficient mice. Oncogene 20: 5258-5263

46. Gerson SL (2004) MGMT: its role in cancer aetiology and cancer therapeutics. Nat. Rev. Cancer 4: 296-307

47. Bunz F, Dutriaux A, Lengauer C, Waldman T, Zhou S, Brown JP, Sedivy JM, Kinzler KW and Vogelstein B (1998) Requirement for p53 and p21 to sustain G2 arrest after DNA damage. Science 282: 1497-1501

48. Sherr CJ (2004) Principles of tumor suppression. Cell 116: 235-246

49. Zhivotovsky B and Orrenius S (2003) Defects in the apoptotic machinery of cancer cells: role in drug resistance. Semin. Cancer Biol. 13: 125-134

50. Pommier Y, Sordet O, Antony S, Hayward RL and Kohn KW (2004) Apoptosis defects and chemotherapy resistance: molecular interaction maps and networks. Oncogene 23: 2934-2949

51. Altieri DC (2004) Coupling apoptosis resistance to the cellular stress response: the IAP-Hsp90 connection in cancer. Cell Cycle 3: 255-256

52. Liang $\mathrm{J}$ and Slingerland JM (2003) Multiple roles of the PI3K/PKB (Akt) pathway in cell cycle progression. Cell Cycle 2: 339-345

53. Bjornsti MA and Houghton PJ (2004) The TOR pathway: a target for cancer therapy. Nat. Rev. Cancer 4: 335-348

54. Wendel HG, De Stanchina E, Fridman JS, Malina A, Ray S, Kogan S, CordonCardo C, Pelletier J and Lowe SW (2004) Survival signalling by Akt and elF4E in oncogenesis and cancer therapy. Nature 428: 332-337

55. Thompson JE and Thompson CB (2004) Putting the rap on Akt. J. Clin. Oncol. 22: 4217-4226

56. Zhivotovsky B and Kroemer G (2004) Apoptosis and genomic instability. Nat. Rev. Mol. Cell Biol. 5: 752-762

57. Vogelstein B and Kinzler KW (1993) The multistep nature of cancer. Trends Genet. 9: $138-141$
58. Blagosklonny MV (2002) Oncogenic resistance to growth-limiting conditions. Nat. Rev. Cancer 2: 221-225

59. Wille JJJ, Pittelkow MR and Scott RE (1985) Normal and transformed human prokeratinocytes express divergent effects of a tumor promoter on cell cyclemediated control of proliferation and differentiation. Carcinogenesis 6: $1181-1187$

60. Willey JC, Moser CEJ, Lechner JF and Harris CC (1984) Differential effects of 12-O-tetradecanoylphorbol-13-acetate on cultured normal and neoplastic human bronchial epithelial cells. Cancer Res. 44: 5124-5126

61. Blagosklonny MV, Dixon SC, Robey R and Figg WD (2001) Resistance to growth inhibitory and apoptotic effects of phorbol ester and UCN-01 in aggressive cancer cell lines. Int. J. Oncol. 18: 697-704

62. Mitchell K and El-Deiry WS (1999) Overexpression of c-myc inhibits p21WAF1/CIP1 expression and induces S-phase entry in 12-0-tetradecanoylphorbol-13-acetate (TPA)-sensitive human cancer cells. Cell Growth Differ. 10: 223-230

63. Karen J, Wang Y, Javaherian A, Vaccariello M, Fusenig NE and Garlick JA (1999) 12-O-tetradecanoylphorbol-13-acetate induces clonal expansion of potentially malignant keratinocytes in a tissue model of early neoplastic progression. Cancer Res. 59: 474-481

64. Siegel PM and Massague J (2003) Cytostatic and apoptotic actions of TGFbeta in homeostasis and cancer. Nat. Rev. Cancer 3: 807-820

65. Markowitz S, Wang J, Myeroff L, Parsons R, Sun L, Lutterbaugh J, Fan RS, Zborowska E, Kinzler KW and Vogelstein B (1995) Inactivation of the type II TGF-beta receptor in colon cancer cells with microsatellite instability. Science 268: 1336-1338

66. Cui W, Fowlis DJ, Bryson S, Duffie E, Ireland H, Balmain A and Akhurst RJ (1996) TGFbeta1 inhibits the formation of benign skin tumors, but enhances progression to invasive spindle carcinomas in transgenic mice. Cell 86: 531-542

67. Tang B, Vu M, Booker T, Santner SJ, Miller FR, Anver MR and Wakefield LM (2003) TGF-beta switches from tumor suppressor to prometastatic factor in a model of breast cancer progression. J. Clin. Invest. 112: 1116-1124

68. Judah DJ, Legg RF and Neal GE (1977) Development of resistance to cytotoxicity during aflatoxin carcinogenesis. Nature 265: 343-345

69. Gabrielson EW, Van der Meeren A, Reddel RR, Reddel H, Gerwin BI and Harris CC (1992) Human mesothelioma cells and asbestos-exposed mesothelial cells are selectively resistant to amosite toxicity: a possible mechanism for tumor promotion by asbestos. Carcinogenesis 13: 1359-1363

70. Miyashita M, Willey JC, Sasajima K, Lechner JF, LaVoie EJ, Hoffmann D, Smith M, Trump BF and Harris CC (1990) Differential effects of cigarette smoke condensate and its fractions on cultured normal and malignant human bronchial epithelial cells. Exp. Pathol. 38: 19-29

71. Rodin SN and Rodin AS (2000) Human lung cancer and p53: the interplay between mutagenesis and selection. Proc. Natl. Acad. Sci. USA 97: 12244-12249

72. Jonason AS, Kunala S, Price GJ, Restifo RJ, Spinelli HM, Persing JA, Leffell DJ, Tarone RE and Brash DE (1996) Frequent clones of p53-mutated keratinocytes in normal human skin. Proc. Natl. Acad. Sci USA 93: $14025-14029$

73. Rossiter H, Beissert S, Mayer C, Schon MP, Weinrich BG, Tschachler E and Kupper TS (2001) Targeted expression of bcl-2 to murine basal epidermal keratinocytes results in paradoxical retardation of ultraviolet- and chemicalinduced tumorigenesis. Cancer Res. 61: 3619-3626

74. Hart BA, Potts RJ and Watkin RD (2001) Cadmium adaptation in the lung - a double-edged sword? Toxicology 160: 65-70

75. Kerbel RS and Davies AJS (1982) Facilitation of tumor progression by cancertherapy. Lancet 2: 977-978

76. Imamura F, Horai T, Mukai M, Shinkai K and Akedo H (1990) Potentiation of invasive capacity of rat ascites hepatoma cells by adriamycin. Cancer Res. 50: 2018-2021

77. Liang Y, Meleady P, Cleary I, McDonnell S, Connolly L and Clynes M (2001) Selection with melphalan or paclitaxel (Taxol) yields variants with different patterns of multidrug resistance, integrin expression and in vitro invasiveness. Eur. J. Cancer 37: 1041-1052

78. Liang Y, O'Driscoll L, McDonnell S, Doolan P, Oglesby I, Duffy K, O'Connor R and Clynes M (2004) Enhanced in vitro invasiveness and drug resistance with altered gene expression patterns in a human lung carcinoma cell line after pulse selection with anticancer drugs. Int. J. Cancer 111: 484-493 
79. Glynn SA, Gammell P, Heenan M, O'connor R, Liang Y, Keenan J and Clynes $M$ (2004) A new superinvasive in vitro phenotype induced by selection of human breast carcinoma cells with the chemotherapeutic drugs paclitaxel and doxorubicin. Br. J. Cancer 91: 1800-1807

80. Ding Z, Yang X, Chernenko G, Tang SC and Pater A (2000) Human papillomavirus type 16-immortalized endocervical cells selected for resistance to cisplatin are malignantly transformed and have a multidrug resistance phenotype. Int. J. Cancer 87: 818-823

81. Chen CD, Welsbie DS, Tran C, Baek SH, Chen R, Vessella R, Rosenfeld MG and Sawyers $\mathrm{CL}$ (2004) Molecular determinants of resistance to antiandrogen therapy. Nat. Med. 10: 33-39

82. Blagosklonny MV (2003) Tissue-selective therapy of cancer. Br. J. Cancer 89: $1147-1151$

83. O'Dwyer ME, Mauro MJ, Kurilik G, Mori M, Balleisen S, Olson S, Magenis E, Capdeville R and Druker BJ (2002) The impact of clonal evolution on response to imatinib mesylate (STI571) in accelerated phase CML. Blood 100: 1628-1633

84. Luzzatto L, Frassoni F and Melo JV (2002) Imatinib: can one outwit chronic myeloid leukemia? Haematology 87: 898-901

85. Shah NP and Sawyers CL (2003) Mechanisms of resistance to STI571 in Philadelphia chromosome-associated leukemias. Oncogene 22: 7389-7395

86. Donato NJ, Wu JY, Stapley J, Gallick G, Lin H, Arlinghaus R and Talpaz M (2003) BCR-ABL independence and LYN kinase overexpression in chronic myelogenous leukemia cells selected for resistance to STI571. Blood 101 690-698

87. Blagosklonny MV (2004) Antiangiogenic therapy and tumor progression Cancer Cell 5: 13-17

88. Smith MA, McCaffrey RP and Karp JE (1996) The secondary leukemias: challenges and research directions. J. Natl. Cancer Inst. 88: 407-418

89. Bhatia S and Sklar C (2002) Second cancers in survivors of childhood cancer. Nat. Rev. Cancer 2: 124-132

90. Neglia JP, Meadows AT, Robison LL, Kim TH, Newton WA, Ruymann FB, Sather HN and Hammond GD (1991) Second neoplasms after acute lymphoblastic leukemia in childhood. N. Engl. J. Med. 325: 1330-1336

91. Neglia JP, Friedman DL, Yasui Y, Mertens AC, Hammond S, Stovall M, Donaldson SS, Meadows AT and Robison LL (2001) Second malignant neoplasms in five-year survivors of childhood cancer: childhood cancer survivor study. J. Natl. Cancer Inst. 93: 618-629

92. Voso MT, Scardocci A, Guidi F, Zini G, Di Mario A, Pagano L, Hohaus S and Leone $\mathrm{G}$ (2004) Aberrant methylation of DAP-kinase in therapy-related acute myeloid leukemia and myelodysplastic syndromes. Blood 103: 698-700

93. Le Vu B, de Vathaire F, Shamsaldin A, Hawkins MM, Grimaud E, Hardiman C, Diallo I, Vassal G, Bessa E, Campbell S, Panis X, Daly-Schveitzer N, Lagrange JL, Zucker JM, Eschwege F, Chavaudra J and Lemerle J (1998) Radiation dose, chemotherapy and risk of osteosarcoma after solid tumours during childhood. Int. J. Cancer 77: 370-377

94. Hawkins MM, Wilson LM, Burton HS, Potok MH, Winter DL, Marsden HB and Stovall MA (1996) Radiotherapy, alkylating agents, and risk of bone cancer after childhood cancer. J. Natl. Cancer Inst. 88: 270-278

95. Felix CA (1998) Secondary leukemias induced by topoisomerase-targeted drugs. Biochim. Biophys. Acta 1400: 233-255

96. Giovannini M (2002) Percutaneous alcohol ablation for liver metastasis. Semin. Oncol. 29: 192-195

97. Castaneda F and Kinne RK (2000) Cytotoxicity of millimolar concentrations of ethanol on HepG2 human tumor cell line compared to normal rat hepatocytes in vitro. J. Cancer Res. Clin. Oncol. 126: 503-510

98. Burroughs A, Hochhauser D and Meyer T (2004) Systemic treatment and liver transplantation for hepatocellular carcinoma: two ends of the therapeutic spectrum. Lancet Oncol. 5: 409-418

99. Kindler T, Breitenbuecher F, Marx A, Hess G, Gschaidmeier H, Gamm H, Kirkpatrick CJ, Huber C and Fischer T (2003) Sustained complete hematologic remission after administration of the tyrosine kinase inhibitor imatinib mesylate in a patient with refractory, secondary AML. Blood 101: 2960-2962

100. Rajesh D, Schell K and Verma AK (1999) Ras mutation, irrespective of cell type and 553 status, determines a cell's destiny to undergo apoptosis by okadaic acid, an inhibitor of protein phosphatase 1 and 2A. Mol. Pharmacol. 56: $515-525$
101. Elegbede JA, Hayes K, Schell K, Oberley TD and Verma AK (2002) Induction of apoptosis and inhibition of papilloma formation may signal a new role for okadaic acid. Life Sci. 71: 421-436

102. Guo N, Faller DV and Vaziri C (2002) Carcinogen-induced S-phase arrest is Chk1 mediated and caffeine sensitive. Cell Growth Differ. 13: 77-86

103. Wang JL, Wang X, Wang H, lliakis G and Wang Y (2002) CHK1-regulated $\mathrm{S}$-phase checkpoint response reduces camptothecin cytotoxicity. Cell Cycle 1: 267-272

104. Sun SY, Hail NJ and Lotan R (2004) Apoptosis as a novel target for cancer chemoprevention. J. Natl. Cancer Inst. 96: 662-672

105. Yang CS (1997) Inhibition of carcinogenesis by tea. Nature 389: 134-135

106. Evan Gl, Wyllie AH, Gilbert CS, Littlewood TD, Land H, Brooks M, Waters CM, Penn LZ and Hancock DC (1992) Induction of apoptosis in fibroblasts by Cmyc protein. Cell 69: 119-128

107. Serrano M, Lin AW, McCurrach ME, Beach D and Lowe SW (1997) Oncogenic ras provokes premature cell senescence associated with accumulation of p53 and p16INK4a. Cell 88: 593-602

108. Skorski T (2002) BCR/ABL regulates response to DNA damage: the role in resistance to genotoxic treatment and in genomic instability. Oncogene 21: 8591-8604

109. Bunz F, Hwang PM, Torrance C, Waldman T, Zhang Y, Dillehay L, Williams J, Dutriaux A, Lengauer C, Kinzler KW and Vogelstein B (1999) Disruption of p53 in human cancer cells alters the responses to therapeutic agents. J. Clin. Invest. 104: 263-269

110. Li Y, Sun X, LaMont JT, Pardee AB and Li CJ (2003) Selective killing of cancer cells by beta-lapachone: direct checkpoint activation as a strategy against cancer. Proc. Natl. Acad. Sci. USA 100: 2674-2678

111. Druker BJ (2002) Perspectives on the development of a molecularly targeted agent. Cancer Cell 1: 31-36

112. Druker BJ (2004) Imatinib: paradigm or anomaly? Cell Cycle 3: 833-835

113. Barnes DJ and Melo JV (2002) Cytogenetic and molecular genetic aspects of chronic myeloid leukaemia. Acta Haematol. 108: 180-202

114. Lu C, Speers C, Zhang Y, Xu X, Hill J, Steinbis E, Celestino J, Shen Q, Kim H, Hilsenbeck S, Mohsin SK, Wakeling A, Osborne CK and Brown PH (2003) Effect of epidermal growth factor receptor inhibitor on development of estrogen receptor-negative mammary tumors. J. Natl. Cancer Inst. 95: 1825-1833

115. Torrance CJ, Jackson PE, Montgomery E, Kinzler KW, Vogelstein B, Wissner $A$, Nunes M, Frost $P$ and Discafani CM (2000) Combinatorial chemoprevention of intestinal neoplasia. Nat. Med. 6: 1024-1028

116. Weinstein IB (2002) Cancer. Addiction to oncogenes - the Achilles heal of cancer. Science 29: 63-64

117. Baselga J and Arribas J (2004) Treating cancer's kinase 'addiction'. Nat. Med. 10: $786-787$

118. Boxer RB, Jang JW, Sintasath L and Chodosh LA (2004) Lack of sustained regression of C-MYC-induced mammary adenocarcinomas following brief or prolonged MYC inactivation. Cancer Cell 6: 577-586

119. Giuriato $S$ and Felsher DW (2003) How cancers escape their oncogene habit. Cell Cycle 2: 329-332

120. Karlsson A, Giuriato S, Tang F, Fung-Weier J, Levan $G$ and Felsher DW (2003) Genomically complex lymphomas undergo sustained tumor regression upon MYC inactivation unless they acquire novel chromosomal translocations. Blood 101: 2797-2803

121. Meijer GA, Schroeijers AB, Flens MJ, Meuwissen SGM, van der Valk P, Baak JPA and Scheper RJ (1999) Increased expression of multidrug resistance related proteins Pgp, MRP1, and LRP/MVP occurs early in colorectal carcinogenesis. J. Clin. Pathol. 52: 450-454

122. Becker K, Gregel C, Fricke C, Komitowski D, Dosch J and Kaina B (2003) DNA repair protein MGMT protects against $N$-methyl- $N$-nitrosoureainduced conversion of benign into malignant tumors. Carcinogenesis 24: $541-546$

123. Christmann M, Pick M, Lage $H$, Schadendorf $D$ and Kaina B (2001) Acquired resistance of melanoma cells to the antineoplastic agent fotemustine is caused by reactivation of the DNA repair gene MGMT. Int. J. Cancer 92: 123-129

124. Kelly VP, Ellis EM, Manson MM, Chanas SA, Moffat GJ, McLeod R, Judah DJ, Neal GE and Hayes JD (2000) Chemoprevention of aflatoxin B-1 hepatocarcinogenesis by coumarin, a natural benzopyrone that is a potent inducer of aflatoxin B-1-aldehyde reductase, the glutathione $S$-transferase $\mathrm{A} 5$ 
and $\mathrm{P} 1$ subunits, and $\mathrm{NAD}(\mathrm{P}) \mathrm{H}$ : quinone oxidoreductase in rat liver. Cancer Res. 60: 957-969

125. Greenhalgh DA, Wang XJ, Donehower LA and Roop DR (1996) Paradoxical tumor inhibitory effect of p53 loss in transgenic mice expressing epidermaltargeted v-rasHa, v-fos, or human transforming growth factor alpha. Cancer Res. 56: 4413-4423

126. Rissler $P$, Torndal UB and Eriksson LC (1997) Induced drug resistance inhibits selection of initiated cells and cancer development. Carcinogenesis 18 649-655

127. Conney $\mathrm{AH}$ (2003) Enzyme induction and dietary chemicals as approaches to cancer chemoprevention: the Seventh DeWitt S. Goodman Lecture. Cancer Res. 63: 7005-7031

128. Sawyers $C L$ (2003) Opportunities and challenges in the development of kinase inhibitor therapy for cancer. Genes Dev. 17: 2998-3010

129. Paez JG, Janne PA, Lee JC, Tracy S, Greulich H, Gabriel S, Herman P, Kaye FJ, Lindeman N, Boggon TJ, Naoki K, Sasaki H, Fujii Y, Eck MJ, Sellers WR, Johnson BE and Meyerson M (2004) EGFR mutations in lung cancer: correlation with clinical response to gefitinib therapy. Science 304: 1497-1500

130. Lynch TJ, Bell DW, Sordella R, Gurubhagavatula S, Okimoto RA, Brannigan BW, Harris PL, Haserlat SM, Supko JG, Haluska FG, Louis DN, Christiani DC Settleman J and Haber D A (2004) Activating mutations in the epidermal growth factor receptor underlying responsiveness of non-small-cell lung cancer to gefitinib. N. Engl. J. Med. 350: 2129-2139

131. Sordella R, Bell DW, Haber DA and Settleman J (2004) Gefitinib-sensitizing EGFR mutations in lung cancer activate anti-apoptotic pathways. Science 305: 1163-1167

132. Blagosklonny MV (2003) Targeting cancer cells by exploiting their resistance. Trends Mol. Med. 9: 307-312

133. Ozoren N, Kim K, Burns TF, Dicker DT, Moscioni AD and El-Deiry WS (2000) The caspase 9 inhibitor Z-LEHD-FMK protects human liver cells while permitting death of cancer cells exposed to tumor necrosis factor-related apoptosis-inducing ligand. Cancer Res. 60: 6259-6265

134. Blagosklonny MV (2001) Treatment with inhibitors of caspases, that are substrates of drug transporters, selectively permits chemotherapy-induced apoptosis in multidrug-resistant cells but protects normal cells. Leukemia 15 936-994

135. Reed JC (2003) Apoptosis-targeted therapies for cancer. Cancer Cell 3 : 17-22

136. Houck W, Abonour R, Vance G and Einhorn LH (2004) Secondary leukemias in refractory germ cell tumor patients undergoing autologous stem-cell transplantation using high-dose etoposide. J. Clin. Oncol. 22: 2155-2158
137. Amarante-Mendes GP, Finucane DM, Martin SJ, Cotter TG, Salvesen GS and Green DR (1998) Anti-apoptotic oncogenes prevent caspase-dependent and independent commitment for cell death. Cell Death Differ. 5: 298-306

138. Liu NS and O'Brien S (2002) Spontaneous reversion from blast to chronic phase after withdrawal of imatinib mesylate in a patient with chronic myelogenous leukemia. Leuk. Lymphoma 43: 2413-2415

139. Tsao AS, Kantarjian H, Cortes J, O'Brien S and Talpaz M (2003) Imatinib mesylate causes hypopigmentation in the skin. Cancer 98: 2483-2487

140. Esmaeli B, Prieto VG, Butler CE, Kim SK, Ahmadi MA, Kantarjian HM and Talpaz M (2002) Severe periorbital edema secondary to STI571 (Gleevec). Cancer 95: 881-887

141. Baskaynak G, Kreuzer KA, Schwarz M, Zuber J, Audring H, Riess H, Dorken $B$ and le Coutre $P$ (2003) Squamous cutaneous epithelial cell carcinoma in two CML patients with progressive disease under imatinib treatment. Eur. J. Haematol. 70: 231-234

142. Gambacorti-Passerini C, Piazza R, Tornaghi L, Pilotti S and Pogliani E (2004) Development of c-Kit-expressing small-cell lung cancer in a chronic myeloid leukemia patient during imatinib treatment. J. Natl. Cancer Inst. 96: 1723-1724

143. Houghton JA (1999) Apoptosis and drug response. Curr. Opin. Oncol. 11: 475-481

144. Schmitt CA and Lowe SW (1999) Apoptosis and therapy. J. Pathol. 187: 127-137

145. Sellers WR and Fisher DE (1999) Apoptosis and cancer drug targeting. J. Clin. Invest. 104: 1655-1661

146. Martin SJ and Green DR (1994) Apoptosis as a goal of cancer therapy. Curr. Opin. Oncol. 6: 616-621

147. Lowe SW and Lin AW (2000) Apoptosis in cancer. Carcinogenesis 21 485-495

148. Reed JC (2001) Apoptosis-regulating proteins as targets for drug discovery. Trends Mol Med. 7: 314-319

149. Spierings DC, de Vries EG, Vellenga E and de Jong $S$ (2003) The attractive Achilles heel of germ cell tumours: an inherent sensitivity to apoptosisinducing stimuli. J. Pathol. 200: 137-148

150. Kaufmann SH and Vaux DL (2003) Alterations in the apoptotic machinery and their potential role in anticancer drug resistance. Oncogene 22 $74141-77430$

151. von Eschenbach $A C$ (2003) NCl sets goal of eliminating suffering and death due to cancer by 2015. J. Natl. Med. Assoc. 95: 637-639

152. Blagosklonny MV (2005) How cancer could be cured by 2015. Cell Cycle 4: 269-278 